Отримано: 26 серпня 2018 р.

Прорецензовано: 03 вересня 2018 р.

Прийнято до друку: 10 вересня 2018 р. e-mail: nataljabilous@gmail.com

DOI: $10.25264 / 2311-5149-2018-10(38)-38-44$

Хомюк Наталія Леонідівна,

кандидат економічних наук, докторант кафедри міжнародних економічних відносин та управління проектами, Східноєвропейський національний університет імені Лесі Украйнки

Скрипчук Петро Михайлович,

доктор економічних наук, професор, професор кафедри менеджменту,

Начіональний університет водного господарства та природокористування

\title{
МЕХАНІЗМ І КОНЦЕПТУАЛЬНІ НАПРЯМИ СОЦІО-ЕКОЛОГО-ЕКОНОМІЧНОГО РОЗВИТКУ СІЛЬСЬКИХ ОБ'ЄДНАНИХ ТЕРИТОРІАЛЬНИХ ГРОМАД
}

У статті обтрунтовано актуальність розробки механізму та концептуальних напрямів соціо-еколого-економічного розвитку сільських об'єднаних територіальних громад. Здійснено аналіз процесу децентралізації влади та реформування місиевого самоврядування в Україні. Сформовано власне визначення категорії «сочіо-еколого-економічний розвиток сільських об'єднаних територіальних громад». Запропоновано механізм соціо-еколого-економічного розвитку сільських об 'єднаних територіальних громад, який передбачає запровадження спеціальних інструментів, форм, методів, спрямованих на оптимізацію структури даного процесу.

Ключові слова: децентралізаиія, ОТГ, об'єднана громада, соиіо-еколого-економічний розвиток, сільська територія.

Хомюк Наталья Леонидовна,

кандидат экономических наук, докторант кафедры международных экономических отномений и управления проектами, Восточноевропейский начиональный университет имени Леси Украинки

\section{Скрипчук Петр Михайлович,}

доктор экономических наук, профессор, профессор кафедры менеджмента,

Национальный университет водного хозяйства и природопользования

\section{МЕХАНИЗМ И КОНЦЕПТУАЛЬНЫЕ НАПРАВЛЕНИЯ СОЦИО-ЭКОЛОГО-ЭКОНОМИЧЕСКОГО РАЗВИТИЯ СЕЛЬСКИХ ОБЪЕДИНЕННЫХ ТЕРРИТОРИАЛЬНЫХ ГРОМАД}

В статье обоснована актуальность разработки механизма и концептуальных направлений соиио-эколого-экономического развития сельских объединенных территориальных громад. Осуществлено анализ прочесса децентрализации власти и реформирования местного самоуправления в Украине. Сформировано собственное определение категории «социо-эколого-экономическое развитие сельских объединенных территориальных громад». Предложен механизм соиио-эколого-экономического развития сельских объединенных территориальных громад, предусматривающий введение специальных инструментов, форм, методов, направленных на оптимизацию структуры данного проиесса.

Ключевые слова: деиентрализация, ОТГ, объединенная громада, соиио-эколого-экономическое развитие, сельская территория.

Nataliia Khomiuk,

PhD in Economics, Doctoral student at the Department of International Economic Relations and Project Management, Lesya Ukrainka Eastern European National University

Petro Skrypchuk,

Doctor of economics, Professor, Professor at the Department of Management, National University of Water and Environmental Engineering

\section{MECHANISM AND CONCEPTUAL DIRECTIONS FOR SOCIAL, ECOLOGICAL AND ECONOMIC DEVELOPMENT OF JOINED RURAL TERRITORIAL COMMUNITIES}

The development of theoretical, methodological, conceptual foundations and practical recommendations for the social ecological and economic development of rural joined territorial communities and the diversified development of rural areas in Ukraine are becoming more important and relevant.

The purpose of the article is to substantiate the mechanism and conceptual directions of the social, ecological and economic development of rural joined territorial communities in Ukraine. 
The analysis of the process of decentralization and reform of local self-government in Ukraine is carried out. It is proposed to monitor the decentralization and local self-government reform by introducing the specific indicator "decentralization in the field of ecology».

The author produced own definition of the category «social, ecological and economic development of rural joined territorial communities» explaining it as an expanded process of rural joint territorial communities development ensuring harmonious growth of the economic, social, demographic, ethnic and environmental spheres aimed at optimizing these spheres with the purpose of rational use of natural resources and minimization of anthropogenic impact on the environment.

The proposed in the article mechanism of social, ecological and economic development of rural territorial communities involves the introduction of special tools, forms, methods aimed at optimizing the structure of this process.

The author considers that the consequences of the decentralization processes and the reform of local self-government require substantiation concerning the conceptual directions of social, ecological and economic development of rural territorial communities, implementation of the mechanism of the social, ecological and economic development of rural territorial communities, development and implementation of strategies, programs, plans of purpose which are defined harmonious growth and optimization of economic, social and environmental spheres of of rural joined territorial communities development.

Key words: decentralization, JTCs, joined territorial communities, social, ecological and economic development, rural area.

Постановка проблеми. У квітні 2014 року уряд схвалив Концепцію реформування місцевого самоврядування та територіальної організації влади в Україні [1], яка передбачає децентралізацію, створення належних матеріальних, фінансових та організаційних умов для забезпечення виконання органами місцевого самоврядування власних і делегованих повноважень [2, с. 22]. Тому на сторінках наукових видань, під час науково-практичних конференцій та в політичних колах дуже часто обговорюють проблеми, які пов'язані з адміністративною, бюджетною, фінансовою та земельною децентралізацією та розвитком сільських територій, на яких утворено об'єднані територіальні громади [3]. 3 огляду на це питання, розробки теоретичних, методичних, концептуальних засад і практичних рекомендацій щодо соціо-еколого-економічного розвитку сільських об’єднаних територіальних громад і диверсифікованого розвитку сільських територій в Україні набувають важливого значення для держави і $є$ актуальними на сьогодні.

Аналіз останніх досліджень і публікацій. Питання соціо-еколого-економічного розвитку регіонів викладено в працях Л. В. Антонової, Л. П. Валенкевича, О. О. Павленко, М. З. Згуровського, Ю. М. Харазішвілі та інших. Вагомий внесок у дослідження адміністративно-фінансової децентралізації зробили такі вітчизняні фахівці: В. С. Кравців, О. Й. Вівчар, О. Б. Курило, Н. Г. Синютка, П. В. Жук, М. Ф. Плотнікова, А. В. Мовчанюк, Р. М. Плющ та ін. Віддаючи належне наявним здобуткам, слід зазначити, що недостатньо вивченими залишаються деякі питання, що пов'язані з обгрунтуванням концептуальних напрямів соціо-еколого-економічного розвитку сільських об'єднаних територіальних громад; на сьогодні не розроблено механізм соціо-еколого-економічного розвитку сільських об'єднаних територіальних громад і механізм комплексного моніторингу соціо-еколого-економічного розвитку об'єднаних територіальних громад, а також не виокремлено індикатори оцінки соціо-еколого-економічного розвитку даних громад.

Метою статті є обгрунтування механізму та концептуальних напрямів соціо-еколого-економічного розвитку сільських об’єднаних територіальних громад в Україні.

Виклад основного матеріалу. У перші роки децентралізації (передання частини функцій управління центральних органів влади місцевим органам, розширення повноважень нижчестоящих органів управління за рахунок вищестоящих [4, с. 343]) було прийнято Закони України «Про добровільне об’ єднання територіальних громад», «Про співробітництво територіальних громад», «Про засади державної регіональної політики» та ін. і внесено зміни до Бюджетного та Податкового кодексів.

До основних завдань, що лежать в основі децентралізації, варто віднести:

- передачу повноважень від органів виконавчої влади на рівень територіальних громад і закріплення за ними достатніх фінансових ресурсів;

- чітке розмежування повноважень між органами виконавчої влади та між різними рівнями органів місцевого самоврядування;

- посилення відповідальності органів і посадових осіб місцевого самоврядування за свої рішення перед виборцями і державою [5, с. 7].

Станом на 10 серпня 2018 року в Україні створено 803 об'єднані територіальні громади, з них у 705 уже пройшли вибори до ради, обрані голова ОТГ і старости; 98 - очікують рішення ЦВК про призначення перших виборів [6]. Процес створення нових адміністративних утворень почав відбуватися у 2015 році, і на кінець 2015 року вже налічувалось 159 об'єднаних територіальних громад. Слід відзначити, що їх кількість суттєво збільшувалась щороку, і уже станом на 10 серпня 2018 року нараховується 803 ОТГ. Динаміку їх створення зображено на рис. 1. Площа об’єднаних територіальних громад становить 194,1 тис. км² (34,7\% від загальної площі України), а на їх території проживає 6,8 млн громадян України (19,4\% від загальної кількості населення України). 


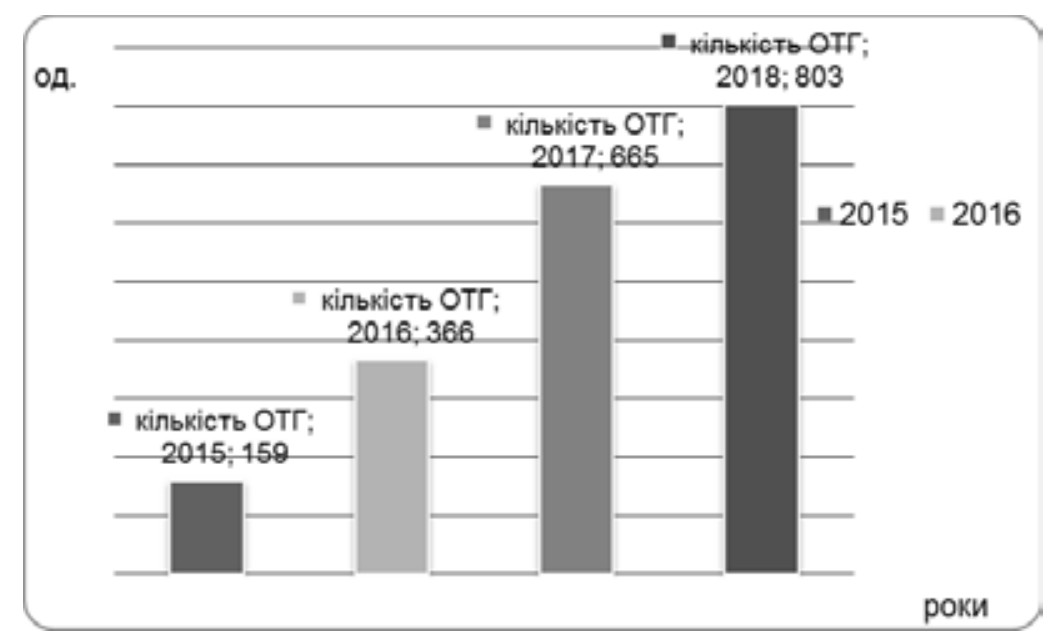

Рис. 1. Кількість об’'днаних територіальних громад станом на 10.08.2018 p.

Джерело: побудовано за даними [6].

Під час національного проекту «Децентралізація» Міністерством регіонального розвитку, будівництва та житлово-комунального господарства України ведеться моніторинг процесу децентралізації влади та реформування місцевого самоврядування, у результаті якого було оприлюднено рейтинг областей щодо формування ОТГ.

У ході моніторингу було виділено 14 ключових індикаторів, які містять:

- перспективні плани, затверджені Урядом, на карті України;

- динаміку формування ОТГ;

- рейтинг областей щодо формування ОТГ;

- інститут старост в об'єднаних громадах;

- співробітництво територіальних громад;

- результати фінансової децентралізації;

- державну фінансову підтримку;

- децентралізацію у сфері охорони здоров'я;

- децентралізацію у сфері освіти;

- децентралізацію повноважень у сфері архітектурно-будівельного контролю;

- децентралізацію у сфері надання адміністративних послуг;

- децентралізацію у сфері соціальної політики;

- децентралізацію у сфері молодіжної політики;

- децентралізацію у сфері земельних відносин.

Такий рейтинг проводять за об'єднаними територіальними громадами, які містять сільські та міські території, тому виокремити дані щодо сільських об'єднаних територіальних громад неможливо, адже деякі ОТГ, окрім сільських територій, містять ще й міські поселення.

Найкращі результати в загальному рейтингу областей щодо формування ОТГ показали Житомирська, Хмельницька, Чернігівська, Волинська, Запорізька та Чернівецька області, а найнижчі - Кіровоградська, Львівська, Київська, Вінницька та Закарпатська області. Основними параметрами такого загального рейтингу є: кількість ОТГ; покриття ОТГ площі області; кількість територіальних громад, що об'єдналися; кількість ОТГ із чисельністю менше 5 тис. осіб; відсоток площі області, охопленої перспективним планом; відсоток населення ОТГ до загальної кількості населення.

Лідерами серед областей за кількості утворених ОТГ є Дніпропетровська (61), Житомирська (51), Запорізька (50), Тернопільська (45), Полтавська (44), Волинська (49) області. Найменше створено ОТГ у Закарпатській, Київській, Харківській і Донецькій областях - відповідно по 6, 12, 16 і 17 ОТГ.

Щоб стимулювати створення об'єднаних громад, у законодавчі документи додано норми про проведення фінансової децентралізації, яка дала змогу ОТГ отримати додатковий ресурс для виконання переданих повноважень. Зокрема, ОТГ отримали повноваження та ресурси, які раніше надавали лише містам обласного значення, а саме - зарахування до місцевого бюджету $60 \%$ податку на доходи фізичних осіб. Крім того, територіальні громади отримують $100 \%$ із єдиного податку, податку на прибуток підприємств і фінансових установ комунальної власності та податку на майно (нерухомість, земля, транспорт); 75\% 3 коштів від відшкодування втрат сільськогосподарського і лісогосподарського виробництва; $50 \%$ відсотків грошових стягнень за шкоду, заподіяну порушенням законодавства про охорону навколишнього природного середовища внаслідок господарської й іншої діяльності; 25\% відсотків екологічного податку 
[7]. 3 другого боку, ОТГ отримали право на державні трансферти для виконання повноважень: дотації, освітню та медичну субвенції, субвенцію на розвиток інфраструктури громад тощо [8].

Проте обмеженість коштів як у Державному бюджеті України, так і в місцевих бюджетах спонукає державні органи, підприємства та наукову спільноту до пошуку варіантів розширення джерел фінансування проектів у різних сферах діяльності.

Співпраця за міжнародними проектами і програмами завжди дає позитивні результати в об'єднанні зусиль дрібних товаровиробників для досягнення поставленої мети, прозорого механізму відбору претендентів для участі в конкурсі, виконання договірних зобов'язань. Міжнародні проекти досить успішно реалізовуються в Україні. Основними донорами для України є США та ЄС. Значні інвестиції надходять із Канади, ФРН, Нідерландів, Швеції, Швейцарії, Японії, Данії, а також від ООН, Світового банку, СБРР, ОЕСР. Більшість міжнародних проектів надають безоплатну допомогу на придбання матеріально-технічних ресурсів для підприємств, які провадять свою діяльність у сільській місцевості, але за умови співфінансування з різними джерелами. Це можуть бути кошти місцевих бюджетів (обласного, районного, сільського, селищного, об’єднаних територіальних громад) і власні кошти підприємств [9].

Підписання Угоди про асоціацію України з СС, як показує досвід країн Центральної та Східної Свропи, відкриває перед сільськими територіальними громадами використання можливостей грантового фінансування, передусім, від європейських донорів, та отримання пільгових кредитів. Це дозволяє місцевим громадам напряму, без посередництва центрального уряду, долучитись до вирішення таких місцевих проблем [10, с. $4-5]$ :

- розбудова та ремонт доріг, водопостачання, каналізації і теплових мереж;

- будівництво та ремонт шкіл, лікарень, дитячих садків, інших соціальних об’єктів;

- запровадження енергоощадних технологій;

- стимулювання підприємництва та сприяння самозайнятості.

Водночас ідеться не тільки про фінансову підтримку розвитку територій, але й технічну допомогу, а саме $[10$, c. $4-5]$ :

- поширення передового європейського досвіду;

- проведення тренінгів, спрямованих на підготовку та перепідготовку працівників органів самоврядування;

- інформаційна підтримка українського бізнесу;

- допомога в пошуку фінансових ресурсів;

- надання консультативної допомоги як щодо питань структурної перебудови економіки, так і виходу українських товаровиробників на європейські ринки тощо.

Із 1 лютого 2018 року Держгеокадастр розпочав процес передачі земельних ділянок сільськогосподарського призначення державної власності в комунальну власність об'єднаних територіальних громад. Крім того, структури Держгеокадастру позбавлені права одноосібно ухвалювати рішення без згоди об'єднаних територіальних громад щодо розпорядження землями поза межами населених пунктів. Станом на 10 серпня 2018 року 251 ОТГ отримала в комунальну власність 387,1 тис. га земель сільськогосподарського призначення.

На думку науковців, головними перевагами децентралізації $\epsilon$, насамперед, краще забезпечення потреб місцевого населення органами місцевого самоврядування на локальному рівні. Крім того, сприяння розвитку конкуренції між органами місцевого самоврядування дає змогу громадянам самим обирати кращі адміністративні послуги [11].

Окрім того, як бачимо, для оцінки процесу децентралізації використані індикатори, які пов'язані 3 розвитком економічної та соціальної сфер. Індикатори, які оцінювали б екологічний стан територій ОТГ, не включені до комплексного аналізу ОТГ. Тому, на нашу думку, для точніших результатів процесу децентралізації влади та реформування місцевого самоврядування необхідно додати індикатор - децентралізація у сфері екології.

Л. П. Валенкевич, О. О. Павленко, Ю. Т. Алібекова для формування оцінки соціо-еколого-економічного розвитку території ввели систему індексів, що сформовані завдяки ряду факторів, які відображають соціальну, екологічну й економічну складові потенціалу регіону. На їх думку, економічна складова розвитку регіону містить такі показники: випуск товарів і послуг, проміжне споживання, споживання основного капіталу, чистий внутрішній продукт, обігові кошти, основні засоби, кількість зайнятих працівників; соціальна - попит і пропозиція робочої сили на ринку праці; навантаження на одне вільне робоче місце; заробітна плата на рівні території, яку досліджують; та екологічна - екологічні платежі, капітальні інвестиції [12].

М. З. Згуровський для оцінки сталого розвитку регіонів України запропонував індикатори, згруповані за параметрами економічного, екологічного та соціально-інституціонального вимірів [13, с. 6-11].

Соціо-еколого-економічний розвиток регіону, як і держави, $є$ інтегральною характеристикою стану економічної системи, оскільки система містить ряд підсистем - найважливіших взаємозв'язаних струк- 
турних складових розвитку економічної системи, які відображають функціонування окремих сфер економіки: економічну - макроекономічну (структурну, формальну та неформальну, інфраструктурну складові), інвестиційно-фінансову (інвестиційну та фінансову складові), інноваційну, зовнішньо-внутрішню, соціально-демографічну (соціальну та демографічну складові), еколого-рекреаційну (рекреаційно-туристичну й екологічну складові). Цей перелік, якій відображає соціо-еколого-економічні аспекти розвитку, на думку Ю. М. Харазішвілі, не є догмою, а може доповнюватись або уточнюватись як за складовими, так і за індикаторами в кожній складовій [14].

На нашу думку, соціо-еколого-економічний розвиток сільських об'єднаних територіальних громад - це процес розширеного відтворення розвитку сільських об'єднаних територіальних громад, що забезпечує гармонійне зростання економічної, соціальної, демографічної, етнічної й екологічної сфер, спрямований на оптимізацію таких сфер із метою раціонального використання природних ресурсів $\mathrm{i}$ мінімізації антропогенного впливу на навколишнє середовище. Він повинен проявляється в розширенні сфер зайнятості та доходів сільського населення, належному забезпеченні медичними й освітніми закладами, покращенні дорожньо-транспортної інфраструктури, створенні умов для розвитку альтернативних напрямів підприємництва та їх подальшої диверсифікації на територіях, збереженні та покращенні природних ресурсів.

В основу концептуальних засад соціо-еколого-економічного розвитку сільських об'єднаних територіальних громад покладено реалізацію механізму та застосування заходів, комплексна дія яких має синергетичний характер, акцентуючи водночас увагу на раціональне природокористування і мінімізацію антропогенного впливу на навколишнє середовище.

Механізм соціо-еколого-економічного розвитку сільських об'єднаних територіальних громад (рис. 2) передбачає запровадження спеціальних інструментів, форм, методів, спрямованих на оптимізацію структури процесу.

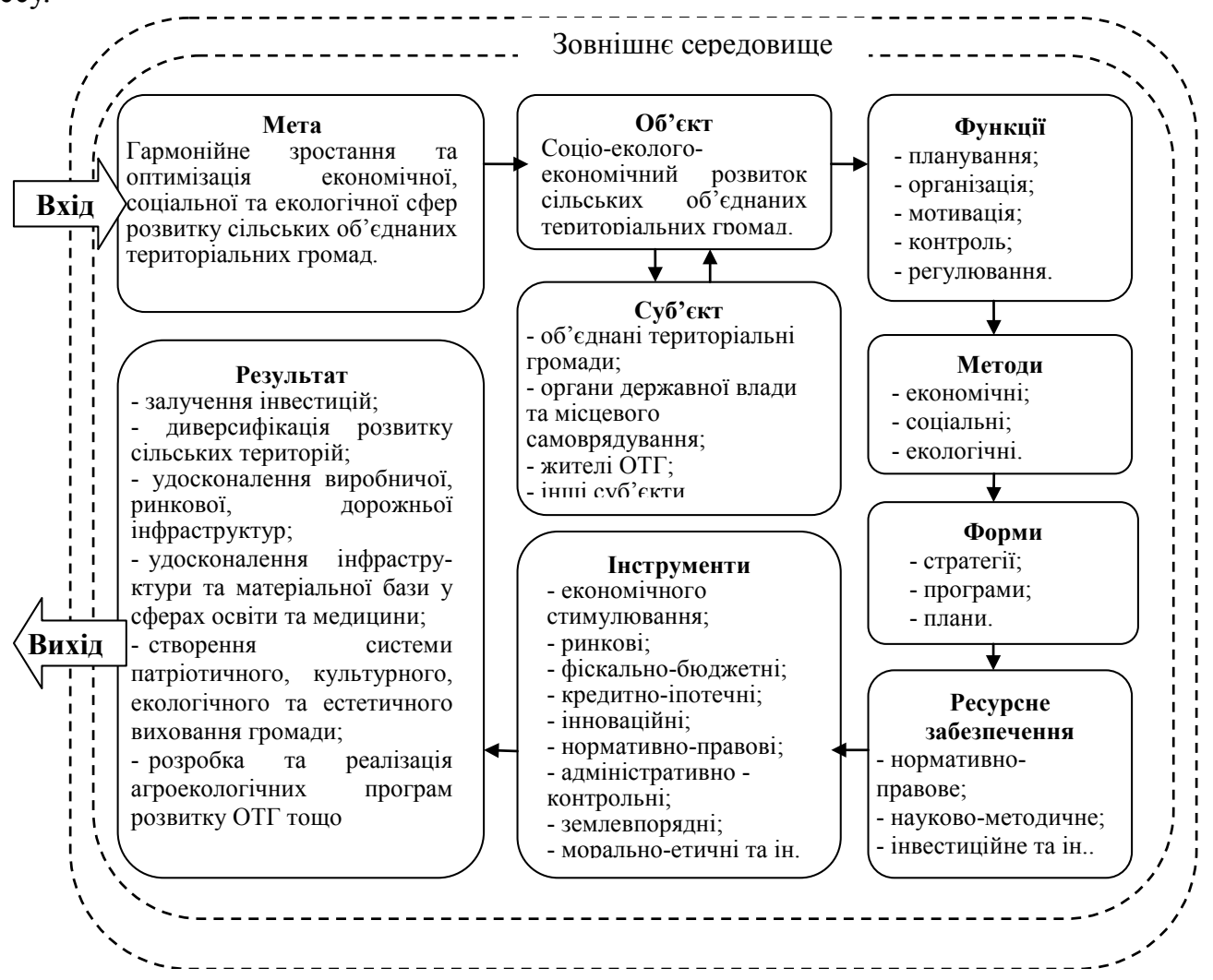

Рис. 2. Механізм соціо-еколого-економічного розвитку сільських об'сднаних територіальних громад

Джерело: розробка авторів.

Концепція соціо-еколого-економічного розвитку сільських об'єднаних територіальних громад має містити розробку стратегій соціо-еколого-економічного розвитку громад (на термін до 10 років), програм соціо-еколого-економічного розвитку громад (на термін до 5 років), річних планів і бюджетів соціо-еколого-економічного розвитку сільських громад.

Першочергова мета переходу до концепції соціо-еколого-економічного розвитку регіону на інноваційній основі, на думку Л. В. Антонової, - збереження статичної та динамічної ефективності, що передбачає створення економічних стимулів шляхом упровадження інновацій, забезпечення привабливості 
місця розташування виробництва і відповідного внеску в загальноукраїнську економічну стабільність. Головна мета державного регулювання соціо-еколого-економічного розвитку регіону - довгострокове забезпечення добробуту населення та можливостей регенерації природної системи. Для цього потрібно скоротити видобуток первинних енергоносіїв, знизити рівень загального вилучення сировини з природи, а також зменшити негативні наслідки від використання земельних ресурсів, активно захищати біологічне різноманіття навколишнього середовища, знизити рівень ризику технічних помилок, наприклад, щодо використання атомної енергії [15].

3 огляду на міжнародні стандарти та вимоги, а також враховуючи внутрішні потреби сільських територій, доцільно в національну політику імплементувати засади соціо-еколого-економічного розвитку сільських ОТГ, а державну підтримку зосередити на таких напрямах:

\section{Економічна сфера:}

- створення умов для залучення інвестицій;

- диверсифікація сільськогосподарського виробництва;

- диверсифікація несільськогосподарської діяльності;

- надання державної підтримки малим і середнім господарствам;

- сприяння сільськогосподарським виробникам у збільшенні доданої вартості сільськогосподарської продукції через зберігання, переробку, торгівлю, маркетинг, підтримку створення й розвитку кооперативів;

- удосконалення виробничої, ринкової, дорожньої інфраструктур для розвитку сільського господарства.

\section{Соціальна сфера:}

- створення системи культурного й естетичного виховання громади;

- консультаційне забезпечення, навчання і підвищення кваліфікації сільських жителів;

- надання допомоги молодим сільськогосподарським виробникам;

- укладання і гарантування дотримання трудових контрактів найманих працівників з адміністрацією роботодавця;

- удосконалення інфраструктури та матеріальної бази у сферах освіти та медицини.

\section{Екологічна сфера:}

- створення системи екологічного та патріотичного виховання громади;

- відповідальність за стан і тенденції в довкіллі на території ОТГ;

- облаштування раціональних агроландшафтів;

- консервація деградованих малопродуктивних сільськогосподарських земель, створення на них культурних пасовищ і лісонасаджень;

- виконання робіт із запобігання ерозійним і зсувним процесам;

- розробка та реалізація агроекологічних програм розвитку ОТГ.

Головним засобом забезпечення розвитку сільських території є диверсифікація розвитку сільських територій, яку розглядають як комплекс заходів, спрямованих на урізноманітнення сільськогосподарської та несільськогосподарської діяльності на сільських територіях, розширення джерел фінансування програм сільського розвитку та заходів, організованих об'єднаними територіальними громадами 3 метою розширення сфер зайнятості та доходів сільського населення на основі системного підходу й через реалізацію процедур інформаційного забезпечення (екологічні експертиза й аудит територій, стратегічна екологічна оцінка, експертні оцінки завдяки процедурам моніторингу соціо-еколого-економічних показників) [16].

Висновки. Врахування наслідків процесів децентралізації влади та реформування місцевого самоврядування вимагає обгрунтування концептуальних напрямів соціо-еколого-економічного розвитку сільських об'єднаних територіальних громад, реалізації механізму соціо-еколого-економічного розвитку сільських об'єднаних територіальних громад, розробки та впровадження стратегій, програм, планів метою яких визначено гармонійне зростання й оптимізація економічної, соціальної й екологічної сфер розвитку сільських об'єднаних територіальних громад.

\section{Література:}

1. Про схвалення Концепції реформування місцевого самоврядування та територіальної організації влади в Україні. Розпорядження Кабінету Міністрів України від 01.04.2014 № 333-p. URL: http://zakon2.rada.gov.ua/ laws/show/333-2014-\%D1\%80 (дата звернення 15.08.2018).

2. Місцеве самоврядування в умовах децентралізації влади в Україні: колективна монографія / Р. М. Плющ та ін. К.: Рідна мова, 2016. 744 с.

3. Павліха Н. В., Хомюк Н. Л. Децентралізація в Україні: стан та вплив ії на розвиток сільських територій. Актуальні проблеми регіональних досліджень : матеріали II Міжнар. наук.-практ. інтернет-конференцїі (Луцьк, 17-18 трав. 2018 р.). Луцьк : Вежа-Друк, 2018. - С. 16-19.

4. Економічна енциклопедія: у 3 т. Т. 1 / за ред. С. В. Мочерного та ін. К.: ВЦ «Академія». 2000. 864 с.

5. Лелеченко А. П., Васильєва О. І., Куйбіда В. С., Ткачук А. Ф. Місцеве самоврядування в умовах децентралізації повноважень: навч. посіб. К. : 2017. 110 с. 
6. Моніторинг процесу децентралізації влади та реформування місцевого самоврядування станом на 10 квітня 2018 року. URL: https://decentralization.gov.ua/mainmonitoring.

7. Бюджетний кодекс України від 08.07.2010 № 2456-VI. URL: http://zakon2.rada.gov.ua/laws/show/2456-17.

8. Ярощук О. Рубікон децентралізації - успіхи головної реформи останніх 4 років. URL: https://agropolit. com/spetsproekty/425-rubikon-detsentralizatsiyi-uspihi-golovnoyi-reformi-ostannih-4-rokiv

9. Приліпко С. М., Макушок О. В. Роль міжнародних проектів технічної допомоги у розвитку обслуговуючої кооперації сільських територій. Житомир: Вид-во «Житомирський національний агроекологічний університет», 2017. URL: http://ir.znau.edu.ua/bitstream/123456789/8580/1/Cooperative 2017 107-113.pdf.

10. Бочі А., Поворозник В., Шилепницький П. Де знайти гроші сільським громадам: перспективи і можливості фінансування міжнародними донорами. - Міжнародний центр перспективних досліджень, 2015.52 с.

11. Вівчар О. Й. Курило О. Б., Синютка Н. Г. Децентралізація в Україні: стан та перспективи провадження реформи. Економічний форум. 2018. № 1. с. 55-62.

12. Валенкевич Л. П., Павленко О. О., Алібекова Ю. Т. Обгрунтування оцінки соціо-еколого-економічного розвитку адміністративно-териториторіальної одиниці. Механізм регулювання економіки. 2012. № 3. С. 16-25.

13. Згуровський М.З. Сталий розвиток регіонів України. К.: НТУУ «КПІ», 2009. 197 с.

14. Харазішвілі Ю. М. Соціо-еколого-економічний розвиток регіонів 3 позицій економічної безпеки (на прикладі Донецької області). Вісник економічної науки України. 2016. № 1 (30). С. 149-158.

15. Антонова Л. В. Державне регулювання соціо-еколого-економічного розвитку регіонів України на інноваційній основі. Наукові праці. Серія: Державне управління. 2015. Т. 263.Вип. 252. С. 6-10.

16. Хомюк Н.Л. Диверсифікація розвитку сільських територій як економічна категорія // Організаційноекономічні засади інформаційного забезпечення економіки. Колективна монографія. Рівне: НУВГП, 2018. C. $232-242$. 